\title{
Does Online Political Participation Reinforce Offline Political Participation?: Using Instrumental Variable
}

\author{
WookJoon Sung \\ Seoul National University of Science and Technology \\ wjsung@seoultech.ac.kr
}

\author{
Changki Jang \\ Seoul National University of Science and Technology \\ changki361@hotmail.com
}

\begin{abstract}
The purpose of this study is to investigate whether online political participation can predict the strengthening of offline political participation by using privacy concerns as an instrumental variable. Accordingly, the 2SLS analysis was applied using the Korea Media Panel Survey data of 2016 conducted by the Korea Information Society Development Institute (KISDI). As a result, age and ideological inclination were found to be more important factors in offline political participation than by socioeconomic status. In addition, the use of an instrumental variable to control the direction of causality indicates that online political participation reinforces offline political participation. As a result of habituated daily online activities, it is suggested that a new participatory group, especially low socioeconomic strata, may be mobilized due to the influence of online political participation. This research eliminating the possibility of two-way causality between online and offline political participation is meaningful in finding that online participation activities can reinforce offline political participation and that it is possible to mobilize the groups that were alienated from offline political participation.
\end{abstract}

\section{Introduction}

As online activities based on the Internet and social networks become commonplace, discussions about online political participation have been actively conducted. The development of information and communication technology has made online activities exceed the limits of time and space constraints. In other words, people can search for and receive the information they want at anytime and anywhere in the online environment. Because of this online nature, news providers are constantly providing online news, and politicians are using it to promote their policies.
Therefore, there is a continuing debate that individual citizens are increasingly likely to participate in politics through online activities, and that online activity will strengthen political participation, and that participation may be frustrated due to confirmation bias $[25,39,40]$.

Online activities also increase the likelihood that individual citizens will be able to participate in politics by reducing the cost of accessing information[13, 21]. Unlike the traditional political participation area, the online area can enable individual citizens to form a relatively equal relationship to access to information and freely express their opinions without competition issues. Of course, social context and interaction with other people can be a factor to stimulate political participation[25], but the online characteristics are becoming important factors to increase the possibility of individual citizens to participate in politics by forming diverse networks.

There is little research on whether political participation through online activities affects offline political participation. Most studies focus on the impact of online activities on online political participation[14, 21, 27]. However, it is necessary to examine whether political participation through online activities is different from traditional political participation when the infrastructure and conditions for online activities are provided and online activities of individual citizens become common[6, 7]. Therefore, this research will focus on the question of whether everyday online activities of individual citizens will affect offline political participation.

The purpose of this research is to investigate the effect of online participation on offline political participation. Although there are some opinions that online political participation reinforces offline political participation due to the activities of young people who are well adapted to the online environment, it is not yet clear whether this is a temporary social phenomenon or a process of transformation[6, 7, 28]. Therefore, this research will examine empirically the effects of online political 
participation on offline political participation after reviewing the existing discussion on political participation through theoretical and literature review on political participation.

\section{Theoretical and Literature review}

\subsection{Political participation in the digital age}

Political participation refers to citizen activities that affect politics[11]. It is defined as an activity taken by an individual citizen for the purpose of almost directly affecting the choices and actions of politicians[38]. Individual citizens influence both government decisions and non-decisions through political participation, influencing the authoritative allocation of values for society[38]. Individual citizens participate in politics in various forms of activity, such as voting, contacting political officials, attending a rally, signing petitions, participating in political campaigns, giving political contributions, and volunteering for politics[16, 35].

Political participation is influenced by mass media. Broadcasting and newspapers, which are traditional mass media, have contributed a lot to form a public opinion for political participation. In the digital age, activities to exchange information and make public opinion through online are highlighted, and their importance is increasing. Like traditional media such as broadcasting and newspapers, Internet media help citizens get the information they need about voting, stimulate citizens' interest in elections, and increase turnout[35].

However, Internet media shows different aspects of influence on political participation than traditional media. The Internet, the core medium of the digital age, facilitates communication flexibility, alleviating time and space constraints and allowing users to rapidly communicate large amounts of information[35]. In addition, the online environment has the potential to create new forms of political action and has greater influence than traditional media[16, 32]. Accordingly, in order to distinguish political participation between the online and offline environments, this research classified the participatory forms with traditional media as offline political participation and participation through online activities as online political participation.

The activities for political participation are categorized according to the degree of participation and the concept of participation. First, it is classified as participation and passive engagement depending on the degree of participation[16]. The types of activities of participation include voting, party and campaign activities, rallies, contact, collective action, and consumerism. On the other hand, the types of activities of passive engagement include news subscriptions, discussion on politics, political expression. Second, the classification of political participation according to the level of participation concept is classified according to concept definition, a target level of participation activity (government, politics, country, problem issue or community) and motivation[11]. These classifications also suggest online political participation activities that correspond to offline participation activities.

Norris (2000) grouped discussions on online political participation according to the role and influence of internet media on political participation as mobilization thesis and reinforcement thesis. First, the mobilization thesis is that the use of the Internet will facilitate and encourage new forms of political activity, and it will increase the participation of new groups that are different from previous ones in participating groups according to socioeconomic status. Next, the reinforcement thesis suggests that the use of the Internet will strengthen existing forms of citizen involvement rather than radical change.

The possibility of intensifying participation inequality among people who do not use the Internet in terms of the digital divide remains a problem[16]. As a key element of participation in digital networks, actions for digital communication are essential to political participation, and exclusiveness of selfexpression, identity, and personalized elements (network and personalized content) is part of the action[34]. In the digital age, the inequality of participation is determined by how many social networking relationships they have, and these online networks themselves are an important resource. In addition, the technical factors that make the internet available for online political participation are also factors that may affect the inequality of participation[22].

Online political participation is also an important factor in the realization of the digital government. Digital government is the use of information technology to increase the convenience and accessibility of government services to citizens so that services and information can be delivered efficiently[10, 15]. The realization of the digital government is a mechanism for improving civic participation, democratic values, government accountability and transparency[2]. This shows the possibility that citizens' level of online political participation can be an indicator of how much digital government is realized. In order to expand online political participation, institutions and levels of technological progress must be combined and the 
government's response to participation must be satisfactory[19, 20, 23]. Citizens' online political participation is facilitated mainly through the exchange of opinions through social media platforms, in which policymakers play an important role in establishing policy networks and connecting ordinary citizens to policy[12, 29]. Therefore, in order to realize transparent and efficient digital government, it is necessary to have a policy decision and infrastructure that can induce citizens' voluntary participation.

The purpose of this research is to examine whether online political participation strengthens offline political participation as a result of this theoretical discussion. In the digital age, the Internet media is an important mediator of public opinion. As a result of the mobilization debate, it is important to act in the Internet media and the digital network as a factor to attract political participation of the young people who are participating in the election for the first time. However, there is a need to continue discussions as to whether these young people continue to engage in activities over time. In addition, it is important that online political participation leads to offline participation in reflecting citizen's demands on politics. Therefore, this research focuses on reinforcing offline participation of online political participation.

\subsection{Literature review}

Research on online political participation consists mainly of empirical studies on mobilization thesis and reinforcement thesis. These empirical studies are mostly about how online media use affects political participation. On the other hand, there is not much research on the effect of online political participation or activity on offline political participation. Therefore, the focus of the literature review is on what are the issues of mobilization thesis and reinforcement thesis, and what are the important influential factors in political participation.

First, the mobilization thesis argues that the use of online media serves to mobilize the participation of new strata that have not participated in politics. Most of these studies are explaining the political participation of young people entering the political activities for the first time as the participatory cost is reduced, unlike the existing socioeconomic status [8, $18,21,28,35]$. According to this view, using online media, not to replace the traditional media, is a major factor that young voters are actively engaged in online activities to attract participation[18].

Although there is no big change in the traditional socioeconomic status required for participation, there are some views that the Internet media may improve the inequality of participation for young people who are participating in the election for the first time[30]. Nonetheless, given the equal opportunity to access online, the use of Internet media is likely to involve a new group different from traditional participation in the political process[21]. In this mobilization thesis, there is no question of facilitating the participation of young people who are the first to participate in politics, but there is a contradictory view on the role of existing socioeconomic status.

Secondly, in the reinforcement thesis, it argues that the use of online media plays a role in strengthening offline political participation, though it does not make a big difference to the existing participation level. These studies have mainly conducted empirical studies on the argument that the use of online media improves the quantity and quality of participation activities and reinforces political participation $[6,7,13,14,16,39]$. The use of online media positively affects political participation, but as the time passes, the magnitude of the change gradually decreases, requiring more discussion as to whether the effect is causal or transformational[6, 7]. Therefore, if online activities are generalized to all levels, online political participation will become more common and citizens' participation in politics will be reinforced.

The focus of the reinforcement thesis is the causal relationship of reinforcement. Whether online activities are strengthening offline political participation, or whether offline activities will enhance online political participation is not yet clear. The more individual citizens engage in off-line organization activities, the more they participate in online activities, and online computer club activities have a positive effect on offline participation[39]. Some researchers believe that online resources facilitate online political participation but do not increase the likelihood of offline political participation[18, 21]. On the other hand, some researchers think that as online organization activities and political participation increase, they become more involved in offline organizational activities and politics[39]. Therefore, in this research, it is analyzed that online political participation strengthens offline political participation, and unlike existing research, it analyzes the influence of online political participation strengthening participation in offline politics by identifying the instrumental variable affecting online political participation only.

The research question in this study is whether the increase of online political participation increases offline political participation when the causality is controlled. If the digital divide on socioeconomic 
status is narrowed and online access costs continue to decline, the impact of age, income, or other resources on online political participation will be much less[13]. In addition, online political participation has evolved into a popular way of involving in politics[34], and it is necessary to measure the impact of online political participation on the offline. However, as shown in the results of the literature review, there is a high possibility of two-way causality between offline and online political participation. Therefore, the influence of online political participation on offline political participation will be controlled through the instrumental variable to test the following hypothesis.

H1. As an individual citizen's online political participation becomes more active, offline political participation will be reinforced.

Finally, in addition to socioeconomic status and demographic variables, individual characteristics such as interest in politics and ideological orientation are discussed as factors affecting online and offline political participation. The ideological tendency, which represents the support of a party, is more interested in the news of the supportive tendency, and it decreases the political involvement as it is exposed to the opinion opposite to the support tendency of the individual[13, 24, 25, 28]. On the other hand, there are also some studies that the intensity of political support is not statistically significant with increasing turnout or online political participation[31]. Income, education, and gender are also identified as factors affecting offline and online political participation[8, 18]. On the other hand, traditional socioeconomic factors such as income, education level, and gender appear to have no effect on traditional participation and online participation[13, 30, 31].

H2. Higher socioeconomic status (education and income levels) will have a positive effect on offline political participation.

H3. As the ideological support inclination (liberal and conservative) becomes clearer, it will have a positive effect on offline political participation rather than politically neutral position.

H4. There will be a difference in offline political participation depending on age and gender.

\section{Data and methodology}

\subsection{Research data}

In this research, Korea Media Panel survey data of 2016 conducted by the Korea Information Society
Development Institute (KISDI) is used. In order to provide information for analyzing the effect of media environment change on the media use behavior of households and individuals, KISDI has established a household unit panel since 2010 and has conducted an annual survey. The Korea Media Panel survey mainly includes the status of media devices, media device connectivity, media diary, media usage behavior, subscription and expenditure on broadcasting and communication services, ecommerce and telecommunication usage. The reason for using the 2016 survey data in this research is that the survey items corresponding to the purpose of the research are included only in the 2016 survey.

In the 2016 survey, 9,788 respondents from a total of 4,233 households were interviewed for about two months from June. The Korean media panel survey basically maintained a panel of 5,000 households in proportion to the number of households nationwide, and the surveyors visited each household and conducted an interview survey. Panelists surveyed households aged 6 and over, but this study analyzed respondents aged 19 or older who are eligible to participate in the election in Korea. Therefore, in this research 8,439 respondents excluded under 19 years of age from all respondents were used in the analysis.

According to the National Election Commission of Korea, the gender distribution of the 20th National Assembly elections in 2016 was $49.5 \%$ for males and $50.5 \%$ for females. In addition, according to the national statistics portal (kosis.kr) of Statistics Korea, as of 2016, the average monthly income in 2016 is KRW 4.40 million, and the monthly income per 5th quartile is distributed as KRW 1.44 million in the first quartile, KRW 2.91 million in the second quartile, KRW 4 million in the third quartile, KRW 5.72 million in the fourth quartile, and KRW 8.35 million in the fifth quartile. According to the enational index of Korea, education level is $13 \%$ below middle school graduation, $40 \%$ below high school graduation, and $47 \%$ above the higher education level. Therefore, the demographic distribution of the research sample, as shown in Table 2 , can adequately represent the distribution of voters in Korean society.

\subsection{Research methodology}

In this research, two-stage least squares regression analysis (2SLS) using instrumental variable will be conducted to analyze whether online political participation strengthens offline political participation. 2SLS is a technique for estimating the causality between variables by substituting the estimates of the explanatory variables through the 
first-step ordinary least square regression (OLS) and then using second-step regression analysis[36]. Despite the problem of weak instrumental variables with the low accuracy of estimates if there is a partial correlation between instrumental and endogenous variables, 2SLS estimation is one of the most used techniques to solve the bias problem caused by the endogeneity of explanatory variables $[3,17,36]$.

The endogeneity occurs when there is a correlation between the explanatory variables and the error term of the regression model. This occurs mainly due to the simultaneous causal relationship between the variables, the measurement error in the explanatory variables, bias in sample selection, or omitted variables. If an endogenous explanatory variable exists, the estimation using instrumental variables is mainly used to solve it. If there is an available instrument variable that is not related to the effect on the dependent variable, while influencing the explanatory variable, it can help to improve the efficiency of the estimation result and help identify the coefficient of the explanatory variable associated with the effect on the dependent variable[5]. The use of instrumental variables also helps overcome the measurement error of the explanatory variables. Thus, estimation using instrumental variables is a powerful and flexible technique for estimating the effect of causal relationships[1].

It is necessary to select an appropriate instrumental variable in order to effectively measure the effects of online political participation on offline political participation. The instrumental variables should be related to the endogenous explanatory variables without affecting the dependent variables and without correlation with the error term of the regression model[33]. In this research, in order to measure the effect of online political participation on offline political participation, online privacy concern for online participation was selected as an instrumental variable. The level of privacy concerns in an online environment depends on how individuals perceive the situation[9, 37]. However, although there are differences in the perceived level, this privacy concern is presumed to be a cause of reluctance to participate in online politics[30].

The dependent variable in the study is offline political participation. The questionnaire items used in the study consisted of three items: exchange opinions on politics and politicians with the acquaintances, supportive expressions to political parties and politicians, and participation in elections. These items were measured on a 5-point scale (strongly negative to strongly positive). The independent variable is online political participation. In the questionnaire survey on online political participation, three items were used: news subscription to politics, subscription to politics on the internet blog, and expression of opinion on politics and politicians on the Internet. These items were also measured on a 5-point scale (strongly negative to strongly positive). Although these questions were a combination of passive intervention and participation according to the classification of political participation[16], these questions were reduced to a single variable through factor analysis (PCA, principal component analysis) and used as offline and online political participation variables.

The online privacy concern, an instrumental variable, used eight questionnaires. These questionnaires consisted of items such as personal information misuse, concerns about too much information requesting and a 5-point scale (strongly negative to strongly positive). These questionnaires were also reduced to a single variable through factor analysis (PCA) and used as an online privacy concern variable. As shown in Table 1, the results of the factor analysis on the major variables showed somewhat lower confidence in offline political participation, but all the items were applied to the analysis because the questionnaires reflected the offline political participation.

Based on the literature review, the control variables were ideological inclination (single questionnaire item), gender, age, education, and income level. The ideological inclination was measured on a 5-point scale from very liberal to very conservative. However, in this research, those are treated as three dummy variables: strongly liberal and liberal were treated as liberal, strongly conservative and conservative as conservative, and neutral. The gender was male and female, and the age ranged from 19 to 29 , from 30 to 39 , from 40 to 49 , from 50 to 59 , from 60 to 69 , and to over 70 . Education level was classified as below middle school graduation, below high school graduation, and above higher education. The income level was used for the research by referring to the fifth quintile income level in 2016, and it was processed into 7 sections from no income to a monthly average income of over 8 million won.

Therefore, in order to analyze the effects of online political participation on offline political participation, a research model like the following equation was established. In the first stage of estimation, estimates of online political participation are obtained through an instrumental variable, privacy concern, and then applied to the second stage estimation to estimate the parameters for offline political participation. This implies the effect of online political participation on offline political participation. 
Table 1. Results of factor analysis for the major variables.

\begin{tabular}{|c|c|c|c|}
\hline Variables & Questionnaires & Factor & $\begin{array}{l}\text { Cronbach } \\
\text { alpha }\end{array}$ \\
\hline \multirow{3}{*}{$\begin{array}{l}\text { Offline } \\
\text { Political } \\
\text { Participation }\end{array}$} & $\begin{array}{l}\text { I meet with people around me and talk about politics or politicians or share } \\
\text { their opinions. }\end{array}$ & 0.7299 & \multirow{3}{*}{0.5651} \\
\hline & $\begin{array}{l}\text { When I receive a call to ask for a poll, I honestly express my willingness to } \\
\text { support the party or politician. }\end{array}$ & 0.8340 & \\
\hline & I participate in the election. & 0.6245 & \\
\hline \multirow{3}{*}{$\begin{array}{l}\text { online } \\
\text { Political } \\
\text { Participation }\end{array}$} & I regularly search for and read news about politics. & 0.8969 & \multirow{3}{*}{0.8744} \\
\hline & I read posts about politics on the Internet with interest. & 0.9230 & \\
\hline & I talk about politics or politicians on the Internet or share opinions. & 0.8613 & \\
\hline \multirow{8}{*}{$\begin{array}{l}\text { Privacy } \\
\text { Concern }\end{array}$} & $\begin{array}{l}\text { I am worried that someone who does not know will see my online activity } \\
\text { and obtain personal information about me. }\end{array}$ & 0.9025 & \multirow{8}{*}{0.9632} \\
\hline & $\begin{array}{l}\text { I am worried about the information about my old devices (computer, mobile } \\
\text { phone). }\end{array}$ & 0.8889 & \\
\hline & $\begin{array}{l}\text { I am worried that online information on me that I cannot remember will } \\
\text { remain untouched. }\end{array}$ & 0.8806 & \\
\hline & $\begin{array}{l}\text { I am worried about asking too much of my personal information when I sign } \\
\text { up for an online site. }\end{array}$ & 0.8953 & \\
\hline & I'm afraid my online ID will be stolen. & 0.8979 & \\
\hline & I am generally worried about my privacy when using the Internet. & 0.8817 & \\
\hline & People who are reluctant to reveal their information online are doubtful. & 0.9001 & \\
\hline & $\begin{array}{l}\text { I am worried that my pictures, names and other personal information will be } \\
\text { stolen online. }\end{array}$ & 0.8894 & \\
\hline
\end{tabular}

Table 2. Frequency and Descriptive Statistics of Variables

\begin{tabular}{|c|c|c|c|c|c|c|c|c|}
\hline & & & offline $p$ & ticipation & online $\mathrm{p}$ & ticipation & privac & concern \\
\hline & Freq. & Percent & Mean & Std. Dev. & Mean & Std. Dev. & Mean & Std. Dev. \\
\hline Total & 8,439 & 100 & 0.000 & 1.000 & 0.000 & 1.000 & 0.000 & 1.000 \\
\hline ideology & & & & & & & & \\
\hline neutral & 3,023 & 35.82 & -0.114 & 1.002 & -0.060 & 0.953 & 0.072 & 0.915 \\
\hline liberal & 1,706 & 20.22 & 0.195 & 1.032 & 0.366 & 1.025 & 0.300 & 0.861 \\
\hline conservative & 3,710 & 43.96 & 0.003 & 0.969 & -0.039 & 0.992 & -0.172 & 1.115 \\
\hline gender & & & & & & & & \\
\hline female & 4,697 & 55.66 & -0.162 & 0.974 & -0.185 & 0.932 & -0.020 & 1.054 \\
\hline male & 3,742 & 44.34 & 0.204 & 0.995 & 0.225 & 1.034 & 0.025 & 0.930 \\
\hline age & & & & & & & & \\
\hline 19 29 & 1,114 & 13.2 & -0.169 & 1.038 & 0.077 & 0.953 & 0.265 & 0.703 \\
\hline 30 39 & 1,037 & 12.29 & 0.029 & 0.938 & 0.190 & 0.947 & 0.306 & 0.740 \\
\hline $40 \sim 49$ & 1,962 & 23.25 & 0.138 & 0.974 & 0.299 & 1.008 & 0.282 & 0.763 \\
\hline $50 \sim 59$ & 1,681 & 19.92 & 0.113 & 1.000 & 0.165 & 1.026 & 0.032 & 0.851 \\
\hline $60 \sim 69$ & 1,111 & 13.17 & 0.013 & 0.985 & -0.141 & 0.955 & -0.283 & 1.073 \\
\hline 70 or more & 1,534 & 18.18 & -0.207 & 1.007 & -0.452 & 0.855 & -0.531 & 1.416 \\
\hline income & & & & & & & & \\
\hline no income & 2,907 & 34.45 & -0.138 & 0.986 & -0.182 & 0.950 & -0.053 & 1.006 \\
\hline below $1.5 \mathrm{M}$ & 2,109 & 24.99 & -0.102 & 0.987 & -0.265 & 0.892 & -0.178 & 1.213 \\
\hline $1.5 \mathrm{M} \sim 3 \mathrm{M}$ & 2,126 & 25.19 & 0.074 & 0.977 & 0.188 & 0.971 & 0.131 & 0.808 \\
\hline $3 \mathrm{M} \sim 4 \mathrm{M}$ & 772 & 9.15 & 0.304 & 0.947 & 0.510 & 0.986 & 0.240 & 0.769 \\
\hline $4 \mathrm{M} \sim 5.5 \mathrm{M}$ & 403 & 4.78 & 0.413 & 1.039 & 0.820 & 1.040 & 0.264 & 0.806 \\
\hline $5.5 \mathrm{M} \sim 8 \mathrm{M}$ & 101 & 1.2 & 0.508 & 1.116 & 0.804 & 1.011 & 0.265 & 0.785 \\
\hline $8 \mathrm{M}$ or more & 21 & 0.25 & 0.298 & 1.085 & 0.795 & 1.105 & 0.302 & 0.904 \\
\hline education & & & & & & & & \\
\hline below middle & 2,311 & 27.38 & -0.192 & 0.964 & -0.437 & 0.829 & -0.491 & 1.291 \\
\hline high & 2,908 & 34.46 & 0.037 & 0.995 & 0.083 & 0.987 & 0.104 & 0.874 \\
\hline above high & 3,220 & 38.16 & 0.104 & 1.011 & 0.332 & 0.996 & 0.286 & 0.738 \\
\hline
\end{tabular}


(First Stage Regression)

$X_{\text {online }}=\pi_{0}+\pi_{1} Z_{\text {privacy }}+\sum \pi_{i} X_{i}+\epsilon$

(Second Stage Regression)

$Y_{\text {offline }}=\beta_{0}+\beta_{1} X_{\text {online }}+\sum \beta_{i} X_{i}+u$

\section{Results}

This research analyzed the influence of online political participation on offline political participation. First, as shown in Table 2, the distribution of the level of political participation in Korean society was examined through frequency and descriptive statistics on the research samples. In the case of offline and online political participation, males in their 40s (4049) who are liberal with ideological inclinations have a high level of participation. The level of online political participation of younger people under the 40s was higher than offline political participation, while those in their 50s and over showed lower levels of online political participation than offline participation. The distribution of privacy concerns shows the highest level in the 30s (30 39 years).
Next, to identify whether online political participation has a causal effect on offline political participation, as shown in Table 3, OLS and 2SLS analysis are conducted. Instrumental variables can be used to control and identify the effects of reverse causality between independent and dependent variables. The privacy concern is a variable that affects only online political participation and is not related to offline political participation. This excludes the possibility of reverse causality and allows for the net effect of online political participation on offline political participation[4].

As shown in the analysis results, the coefficient in 2SLS, which shows the influence of online political participation on offline political participation, is almost twice as large as that of OLS analysis. This implies that online political participation positively affects offline political participation, which means that the magnitude of the influence is considerably large. On the other hand, the ideological inclination and gender were statistically significant in the OLS analysis, but not in the 2SLS analysis. In addition, income and education levels were more statistically significant in the 2SLS analysis using instrumental variables than in OLS.

Table 3. Results of OLS and 2SLS using an instrumental variable for offline political participation.

\begin{tabular}{|c|c|c|c|c|c|c|}
\hline \multirow{2}{*}{ offline participation } & \multicolumn{3}{|c|}{ OLS } & \multicolumn{3}{|c|}{$2 S L S$} \\
\hline & $B$ & $\mathrm{SE}$ & P-value & $B$ & $\mathrm{SE}$ & P-value \\
\hline online participation & 0.549 & 0.010 & 0.000 & 0.932 & 0.125 & 0.000 \\
\hline $\begin{array}{l}\text { Ideology (=neutral) } \\
\text { liberal }\end{array}$ & 0.096 & 0026 & 0000 & -0003 & 0,042 & 0,947 \\
\hline conservative & 0.064 & 0.021 & 0.002 & 0.033 & 0.025 & 0.178 \\
\hline gender (=female) & 0.139 & 0.022 & 0.000 & 0.036 & 0.041 & 0.374 \\
\hline \multicolumn{7}{|l|}{ age $(=19 \sim 29)$} \\
\hline $30 \sim 39$ & 0.151 & 0.037 & 0.000 & 0.115 & 0.042 & 0.006 \\
\hline $40 \sim 49$ & 0.200 & 0.034 & 0.000 & 0.119 & 0.046 & 0.009 \\
\hline $50 \sim 59$ & 0.245 & 0.037 & 0.000 & 0.171 & 0.047 & 0.000 \\
\hline $60 \sim 69$ & 0.291 & 0.044 & 0.000 & 0.230 & 0.052 & 0.000 \\
\hline 70 or more & 0.231 & 0.046 & 0.000 & 0.229 & 0.050 & 0.000 \\
\hline \multicolumn{7}{|l|}{ income (=none) } \\
\hline below $1.5 \mathrm{M}$ & 0.049 & 0.025 & 0.049 & 0.073 & 0.028 & 0.009 \\
\hline $1.5 \mathrm{M} \sim 3 \mathrm{M}$ & -0.023 & 0.026 & 0.383 & -0.049 & 0.030 & 0.098 \\
\hline $3 \mathrm{M} \sim 4 \mathrm{M}$ & -0.029 & 0.039 & 0.452 & -0.111 & 0.050 & 0.026 \\
\hline $4 \mathrm{M} \sim 5.5 \mathrm{M}$ & -0.115 & 0.049 & 0.020 & -0.301 & 0.081 & 0.000 \\
\hline $5.5 \mathrm{M} \sim 8 \mathrm{M}$ & -0.011 & 0.087 & 0.896 & -0.175 & 0.108 & 0.106 \\
\hline $8 \mathrm{M}$ or more & -0.231 & 0.183 & 0.207 & -0.390 & 0.205 & 0.057 \\
\hline \multicolumn{7}{|l|}{ education (=middle) } \\
\hline high & -0.005 & 0.032 & 0.875 & -0.127 & 0.053 & 0.016 \\
\hline above high & -0.012 & 0.038 & 0.752 & -0.207 & 0.076 & 0.006 \\
\hline Intercept & -0.313 & 0.045 & 0.000 & -0.066 & 0.094 & 0.486 \\
\hline F (Prob) & \multirow{2}{*}{\multicolumn{3}{|c|}{$230.44(0.000)$}} & \multirow{2}{*}{\multicolumn{3}{|c|}{$742.31(0.000)$}} \\
\hline Wald chi2 (Prob) & & & & & & \\
\hline R-squared & \multicolumn{3}{|c|}{0.3175} & \multicolumn{3}{|c|}{0.1952} \\
\hline Adj R-squared & \multicolumn{3}{|c|}{0.3161} & \multirow{2}{*}{\multicolumn{3}{|c|}{8.439}} \\
\hline $\mathrm{N}$ & & 8,439 & & & & \\
\hline
\end{tabular}

${ }^{*}$ Instrument variable for 2SLS: privacy concern 
The results of OLS and 2SLS analysis in Table 3 also showed statistically significant that the off-line political participation was more active as the age increased compared to the 20s. In the case of income level, there was no statistical significance in some sections, but the increased income compared to those with no income showed less likelihood of offline political participation. In the case of educational level, the higher the level, the less likely the participation. On the other hand, although the influence on offline political participation by ideological inclination and gender was not statistically significant in 2SLS using the instrumental variable, in the OLS analysis, the more ideologically liberal or conservative, the more active in offline political participation. There was a positive effect on the offline political participation of males compared to females.

Thus, the results of the 2 SLS analysis using an instrumental variable support hypothesis $\mathrm{H} 1$ that online political participation reinforces offline political participation. On the other hand, the hypothesis $\mathrm{H} 2$ is not supported because some sectors are not statistically significant, and the higher socioeconomic status tends to lower offline political participation. The hypothesis $\mathrm{H} 3$ that the clearer the ideological inclination, the more likely it will affect offline political participation, is not significant in 2SLS analyses using instrumental variables, but is supported in OLS analyses because they are statistically significant. Hypothesis $\mathrm{H} 4$, which sets the difference between genders, is also supported in the OLS analysis that male is more involved in offline political activities than female. In the case of hypothesis $\mathrm{H} 4$ according to age, the hypothesis was supported because the participation became more active as the age increased.

These results support the reinforcement thesis that online participation through the Internet strengthens offline political participation[16]. In addition, although the statistical significance is weak for socioeconomic status, the results suggest that the possibility of offline political participation of low socioeconomic status may be high due to the influence of online political participation[21, 22]. This suggests that it is possible to mobilize a new socioeconomic group, which is presented in the mobilization thesis. On the other hand, rather than supporting the opinions of mobilization thesis on the political participation of young people who are actively engaged in online activities, it is suggested that active online activities in the elderly are leading to offline political participation[28, 39].

\section{Discussions and Implications}

This research is to discuss the effect of online political participation on offline political participation based on mobilization and reinforcement thesis. In particular, it was analyzed by using privacy concerns as an instrumental variable to predict whether online political participation is likely to reinforce offline political participation. Unlike each regression analysis for online political participation and offline political participation, the results of the research showed that the predicting direction of the control variables, such as ideological inclination, gender, age, income, and education level, were different in the analysis of the influence on offline political participation of online political participation using instrumental variable. The results of the research can be summarized as follows:

First, online political participation has been shown to reinforce offline political participation. There is still a question as to whether the effect of political involvement through Internet use is real, but the results of this research show that online participation reinforces offline political participation by controlling the direction of causal relationships through privacy concerns[6]. In particular, online political participation in Korean society was shown to significantly reinforce offline participatory activities through the research result. This may not be independent of the spread of digital devices that help citizens engage in online activities. This reflects the fact that online participation is becoming commonplace by shaping an environment in which online activities can become active with the introduction of digital devices.

Second, the influence of online political participation suggests the possibility of mobilizing a new participatory group that is different from the existing one. The results of a controlled causality confirm that the political participation of citizens in socioeconomically low status can become active. This implies that it does not necessarily participate in politics when the level of resources held by individual citizens must be high, but even if the resource level is low, if the online environment is well equipped, there is a high possibility of participating in politics. This suggests that it is possible to mobilize groups that were not able to participate in politics due to the poverty of their resources.

Finally, age and socioeconomic status were found to be more important factors for offline political participation than ideological inclinations. In other words, the age-based influence was shown to be more active in participating with older people who are traditionally interested in offline politics, and those with lower income and education levels are more 
active in offline political participation. Thus, in Korean society, the elderly with low socioeconomic status are more active in offline political participation.

In the digital information age, the realization of digital government is an inevitable process. The digital government can be realized through a citizencentric approach to use it[26]. The realization of the digital government can be estimated by discussing online political participation centered on the voluntary participation of citizens in government policy. Although this research analyzed the influence of online political participation on offline political participation, it was found that the more active the online political participation, the higher the level of citizens' political participation. Thus, as citizens become more politically engaged online, it will be helpful to realize the digital government. However, it is necessary to supplement the study on how privacy concern used as instrumental variable in this study and technical infrastructure affect the realization of digital government. In addition, political participation is expressed in various forms, but the questionnaire items of the dependent and independent variables used in the research did not represent all of these participation types. Therefore, in future research, it is necessary to consider all these factors for participation behavior.

\section{References}

[1] Abadie, A., J. Angrist, and G. Imbens, "Instrumental Variables Estimates of the Effect of Subsidized Training on the Quantiles of Trainee Earnings", Econometrica 70(1), 2002, pp. 91-117.

[2] Ahn, M.J., and S. Bretschneider, "Politics of EGovernment: E-Government and the Political Control of Bureaucracy", Public Administration Review 71(3), 2011, pp. 414-424.

[3] Andrews, D.W.K., M.J. Moreira, and J.H. Stock, "Performance of conditional Wald tests in IV regression with weak instruments", Journal of Econometrics 139(1), 2007, pp. 116-132.

[4] Angrist, J.D., G.W. Imbens, and D.B. Rubin, "Identification of Causal Effects Using Instrumental Variables", Journal of the American Statistical Association 91(434), 1996, pp. 444-455.

[5] Arellano, M., and O. Bover, "Another look at the instrumental variable estimation of error-components models", Journal of Econometrics 68(1), 1995, pp. 29-51.

[6] Boulianne, S., "Does Internet Use Affect Engagement? A Meta-Analysis of Research", Political Communication 26(2), 2009, pp. 193-211.
[7] Boulianne, S., "Social media use and participation: a meta-analysis of current research", Information, Communication \& Society 18(5), 2015, pp. 524-538.

[8] Brady, H.E., S. Verba, and K.L. Schlozman, "Beyond SES: A Resource Model of Political Participation", The American Political Science Review; Washington 89(2), 1995, pp. 271-294.

[9] Buchanan, T., C. Paine, A.N. Joinson, and U.-D. Reips, "Development of measures of online privacy concern and protection for use on the Internet", Journal of the American Society for Information Science and Technology 58(2), 2007, pp. 157-165.

[10] Carter, L., and F. Bélanger, "The utilization of egovernment services: citizen trust, innovation and acceptance factors", Information Systems Journal 15(1), 2005, pp. 5-25.

[11] van Deth, J.W., “A conceptual map of political participation”, Acta Politica; London 49(3), 2014, pp. 349 367.

[12] Eom, S.-J., H. Hwang, and J.H. Kim, "Can social media increase government responsiveness? A case study of Seoul, Korea", Government Information Quarterly 35(1), 2018, pp. 109-122.

[13] Feezell, J.T., "Predicting Online Political Participation: The Importance of Selection Bias and Selective Exposure in the Online Setting", Political Research Quarterly; Salt Lake City 69(3), 2016, pp. 495509.

[14] Gainous, J., A.D. Marlowe, and K.M. Wagner, "Traditional Cleavages or a New World: Does Online Social Networking Bridge the Political Participation Divide?", International Journal of Politics, Culture, and Society; New York 26(2), 2013, pp. 145-158.

[15] Gajendra, S., B. Xi, and Q. Wang, "E-Government: Public Participation and Ethical Issues", Journal of EGovernance 35(4), 2012, pp. 195-204.

[16] Gibson, R., and M. Cantijoch, "Conceptualizing and Measuring Participation in the Age of the Internet: Is Online Political Engagement Really Different to Offline?", The Journal of Politics 75(3), 2013, pp. 701-716.

[17] Hayakawa, K., and Q. Sun, "Instrumental variable estimation of factor models with possibly many variables", Communications in Statistics - Simulation and Computation 48(6), 2019, pp. 1729-1745.

[18] Jensen, J.L., "Political Participation Online: The Replacement and the Mobilisation Hypotheses Revisited", Scandinavian Political Studies 36(4), 2013, pp. 347-364. 
[19] Jho, W., and K.J. Song, "Institutional and technological determinants of civil e-Participation: Solo or duet?", Government Information Quarterly 32(4), 2015, pp. 488-495.

[20] Kim, S., and J. Lee, "E-Participation, Transparency, and Trust in Local Government", Public Administration Review 72(6), 2012, pp. 819-828.

[21] Krueger, B.S., “Assessing the Potential of Internet Political Participation in the United States: A Resource Approach", American Politics Research 30(5), 2002, pp. 476-498.

[22] Krueger, B.S., "A Comparison of Conventional and Internet Political Mobilization", American Politics Research 34(6), 2006, pp. 759-776.

[23] Larsson, H., and Å. Grönlund, "Future-oriented eGovernance: The sustainability concept in eGov research, and ways forward", Government Information Quarterly 31(1), 2014, pp. 137-149.

[24] Lissitsa, S., "Online political participation, online contacts with out-groups members and social distances", Asian Journal of Communication 27(1), 2017, pp. 18-32.

[25] Mutz, D.C., "The Consequences of Cross-Cutting Networks for Political Participation", American Journal of Political Science 46(4), 2002, pp. 838-855.

[26] Nam, T., "Determining the type of e-government use", Government Information Quarterly 31(2), 2014, pp. 211220.

[27] Norris, P., A Virtuous Circle: Political Communications in Postindustrial Societies, Cambridge University Press, NY, 2000.

[28] Oser, J., M. Hooghe, and S. Marien, "Is Online Participation Distinct from Offline Participation? A Latent Class Analysis of Participation Types and Their Stratification", Political Research Quarterly; Salt Lake City 66(1), 2013, pp. 91-101.

[29] Porwol, L., A. Ojo, and J.G. Breslin, "An ontology for next generation e-Participation initiatives", Government Information Quarterly 33(3), 2016, pp. 583-594.

[30] Schlozman, K.L., S. Verba, and H.E. Brady, "Weapon of the Strong? Participatory Inequality and the Internet", Perspectives on Politics; Cambridge 8(2), 2010, pp. 487509.

[31] Steinberg, A., "Exploring Web 2.0 political engagement: Is new technology reducing the biases of political participation?", Electoral Studies 39, 2015, pp. 102-116.
[32] Strömbäck, J., K. Falasca, and S. Kruikemeier, "The Mix of Media Use Matters: Investigating the Effects of Individual News Repertoires on Offline and Online Political Participation", Political Communication 35(3), 2018, pp. 413-432.

[33] Tchetgen Tchetgen, E.J., and K.E. Wirth, “A general instrumental variable framework for regression analysis with outcome missing not at random", Biometrics 73(4), 2017, pp. 1123-1131.

[34] Theocharis, Y., "The Conceptualization of Digitally Networked Participation", Social Media \& Society 1(2), 2015, pp. 1-14.

[35] Tolbert, C.J., and R.S. McNeal, "Unraveling the effects of the internet on political participation?", Political Research Quarterly; Salt Lake City 56(2), 2003, pp. 175185.

[36] Vansteelandt, S., and V. Didelez, "Improving the robustness and efficiency of covariate-adjusted linear instrumental variable estimators", Scandinavian Journal of Statistics 45(4), 2018, pp. 941-961.

[37] Veltri, G.A., and A. Ivchenko, "The impact of different forms of cognitive scarcity on online privacy disclosure", Computers in Human Behavior 73, 2017, pp. 238-246.

[38] Verba, S., and N.H. Nie, Participation in America: Political Democracy and Social Equality, University of Chicago Press, Chicago, 1987.

[39] Wellman, B., A.Q. Haase, J. Witte, and K. Hampton, "Does the Internet Increase, Decrease, or Supplement Social Capital?: Social Networks, Participation, and Community Commitment", American Behavioral Scientist 45(3), 2001, pp. 436-455.

[40] Westerwick, A., B.K. Johnson, and S. KnoblochWesterwick, "Confirmation biases in selective exposure to political online information: Source bias vs. content bias", Communication Monographs 84(3), 2017, pp. 343-364. 